\title{
Mupasi as cosmic s(S)pirit: The universe as a community of life
}

\begin{tabular}{|c|c|}
\hline \multicolumn{2}{|l|}{$\begin{array}{l}\text { Author: } \\
\text { Kuzipa M.E }\end{array}$} \\
\hline \multicolumn{2}{|c|}{$\begin{array}{l}{ }^{1} \text { Department of Dogmatics } \\
\text { and Christian Ethics, Faculty } \\
\text { of Theology, University of } \\
\text { Pretoria, South Africa }\end{array}$} \\
\hline \multicolumn{2}{|c|}{$\begin{array}{l}{ }^{2} \text { Council for World Mission, } \\
\text { United Kingdom }\end{array}$} \\
\hline \multicolumn{2}{|c|}{$\begin{array}{l}\text { Research Project Registration: } \\
\text { Project Leader: J. Buitendag (1) } \\
\text { Project Number: } 02402343\end{array}$} \\
\hline \multicolumn{2}{|c|}{$\begin{array}{l}\text { Dr Nalwamba is participating } \\
\text { in the research project, } \\
\text { 'Theology of Nature', directed } \\
\text { by Prof. Dr Johan Buitendag, } \\
\text { Department Dogmatics and } \\
\text { Christian Ethics, Faculty of } \\
\text { Theology, University of } \\
\text { Pretoria. }\end{array}$} \\
\hline \multicolumn{2}{|c|}{$\begin{array}{l}\text { Corresponding author: } \\
\text { Kuzipa Nalwamba, } \\
\text { knalwamba@gmail.com }\end{array}$} \\
\hline $\begin{array}{l}\text { Dates: } \\
\text { Received: } 01 \mathrm{~N} \\
\text { Accepted: } 05 \mathrm{~J} \\
\text { Published: } 23\end{array}$ & $\begin{array}{l}\text { May } 2017 \\
\text { July } 2017 \\
\text { Aug. } 2017\end{array}$ \\
\hline \multicolumn{2}{|c|}{$\begin{array}{l}\text { How to cite this article: } \\
\text { Nalwamba, K.M.B., 2017, } \\
\text { 'Mupasi as cosmic s(S)pirit: } \\
\text { The universe as a community } \\
\text { of life', HTS Teologiese } \\
\text { Studies/Theological Studies } \\
73(3) \text {, a4624. https://doi. } \\
\text { org/10.4102/hts.v73i3.4624 }\end{array}$} \\
\hline \multicolumn{2}{|c|}{$\begin{array}{l}\text { Copyright: } \\
\text { ๔ 2017. The Author } \\
\text { Licensee: AOSIS. Thi } \\
\text { is licensed under the } \\
\text { Creative Commons } \\
\text { Attribution License. }\end{array}$} \\
\hline \multicolumn{2}{|l|}{ Read online: } \\
\hline 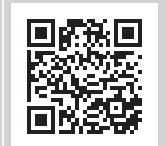 & $\begin{array}{l}\text { Scan this QR } \\
\text { code with your } \\
\text { Smart phone or } \\
\text { mobile device } \\
\text { to read online. }\end{array}$ \\
\hline
\end{tabular}

Mupasi recalls the belief that humans form part of the community of life within the realm of the cosmic spirit. The assertion seems like a truism that requires no further enunciation. However, belief in the Creator-Spirit, a pneuma-theological understanding of creation, is relatively young in the Christian tradition. In Colossians 1:15-20, Christ is presented as instrumental to creation. Christian tradition therefore tends to present creation in Christological terms. The foundational belief in Spirit-Creator-God has not historically undergirded Christian belief about creation. The Christian faith could therefore benefit from 'companion' views of creation in terms of the cosmic spirit. Mupasi is understood as cosmic spirit, the axis of the universe apprehended as an organic whole. The web of life was brought into being, is sustained by, and inhabited by Mupasi. This retrieval has continuities and discontinuities with Christian belief as Spirit-Creator-God. It is presented here as a notion that calls the Christian faith back to its originating intuitions about creation. Mupasi is appropriated within a pneuma-theological framework that addressed a pressing issue of our time, the global ecological crisis. Mupasi presents an ecological critique that is meaningful for a renewed appreciation of community beyond an anthropocentric focus. The cosmic relatedness brings a renewed vision of the universe as a cosmic community of the s(S)pirit. The cultural and intellectual milieu of Mupasi is undergirded by a relational conception of reality. It provides a critical lens with implications for ecclesiology that challenges the church's self-understanding and ways of being.

\section{Introduction}

The belief that humans form part of the community of life within the realm of the cosmic spirit is an assertion that may seem like a truism requiring no further enunciation within Christianity. However, belief in the Creator-Spirit, a pneuma-theological understanding of creation, is relatively young in Christian tradition. Colossians 1:15-20 presents Christ as being instrumental to creation. Hence, Christian tradition tends to present creation in Christological terms that tend to minimise or even exclude the Spirit (Nalwamba \& Buitendag 2017) in its conception of creation.

Ecological awareness continues to challenge Christian self-understanding even as it sharpens a distinctly Christian response to the current ecological crisis the world faces. That double-sided effect of ecological critique on Christian tradition, firstly, has highlighted the brokenness of the earth's 'body' arising from environmental degradation. Secondly, it has challenged dominant theological positions. The ecological wisdom derived from the concept of Mupasi locates human life within an integrated community of life. Locating all of creation within an integrated community of life is, in this discussion, posited to be in critical relationship with an anthropocentric view of creation.

\section{Mupasi: An African conception of s(S)pirit}

Mupasi [cosmic spirit] is the seamless inseparable bond that makes reality one whole, and lends kinship to all creatures (Asante 1985). The Christian faith therefore stands to benefit from this 'companion' and alternative way of seeing the world that affirms the cosmic Spirit beyond Christian epistemological considerations. Some discontinuities notwithstanding, the notion of Mupasi as the life principle is construed here to be in a continuum with the biblical idea of the cosmic spirit as the centre of the universe that holds the cosmic totality as an organic whole. Mupasi is therefore CreatorSpirit, the life principle that vivifies the web of life as well as sustains and inhabits it.

The retrieval of this understanding of the life principle, in that regard, informs Christian theology and calls the Christian faith back to its originating intuitions about creation. The historical transmission of global Christianity has shown that the lens of the 'host' (Walls 1984) culture offers

Note: This article is a reworked version of aspects from the PhD thesis of Kuzipa M.B. Nalwamba, titled 'Vital Force as a Triangulated Concept of Nature and s(S)pirit', in the Department of Dogmatics and Christian Ethics, Faculty of Theology, University of Pretoria with Prof Johan Buitendag as supervisor. 
a translation of the faith in terms that bring the respective cultural imprint to bear on the Christian faith, and that the life principle ontologically integrates all of creation. In this case, Mupasi provides the 'host' lens of the Mambwe culture.

Based on the argument that all creation is God's beloved, the Christian faith acknowledges the special vocation of humans as members of the cosmic community. At the same time, it implies the relatedness of humans to the rest of creation. A renewed vision of the universe as a cosmic community of the Spirit that is relational has implications for ecclesiology. It influences the church's own self-understanding, its ethical responsibility towards creation and its ways of being in the world. Mupasi, in that regard, provides a hermeneutical lens that would contribute to shaping a Christian response to the ecological crisis that is undergirded by a creation theology whose point of departure is the cosmic $s(S)$ pirit. The originating intuitions of the Christian faith about creation and the cultural notion of Mupasi are thus in a pneumatheological conversation.

As Christianity has grown exponentially in numerical terms on the African continent, there is a need for proportionate growth in theological depth. Walls (1984) has aptly observed that:

From Pentecost to the twentieth century, Christian history ... represents its embodiment in a major cultural area, which has meant that ... it has taken an impress from that culture. In each phase, the expression of the Christian faith has developed features, which could only have originated in that culture whose impress it has taken within that phase. (p. 1)

A renewed appreciation of community of life departs from an anthropocentric because it reflects the cosmic relatedness of all creation. It is a renewed vision of the universe as a cosmic community of the s(S)pirit. It is also the telling of the story of the universe, not confined to one view; rather it is one that acknowledges the interrelatedness of the community of life itself. Conradie (2014) offers some advice, in that regard, when he asserts that:

The plausibility of the claim that the world is God's own creation depends on the use of the best available knowledge (scientific and otherwise) of our day. However, the message cannot be derived from that. It is a message that should, in our context, inspire resistance against capitalist exploitation, consumerist greed, cultural alienation and domination in the name of differences of gender, race, class, species and kind. (p. 12)

This article explores the concept of Mupasi, against that background, beginning with a broad exploration of its background, its dimensions and potential for an eco-pneumatheological application. The presupposition is that the notion of Mupasi is a 'dialogue companion' that has potential to inform Christian ecological reflection, thereby contributing the healing of the broken body of creation. By offering it as a hermeneutical lens, Mupasi is a resource that informs and shapes Christian ecological responsibility and action. It is a cultural gift to the wider Christian family as it contributes to the broader global ecological discourse.

\section{Mupasi and vitalism: A brief background}

Mupasi is akin to vitalism, a philosophical concept with origins in life-oriented movements. Vitalism sought to challenge a civilisation that had become intellectualistic and antilife. The contestation about life led to sharp and intricate contrasts about what it means to be living as opposed to being dead or non-living. The distinction between what was living and what was dead became a criterion for cultural criticism among cultural theorists such as Friedrich Nietzsche, Henri Bergson and George Simmel. Traditional ways of thinking were scrutinised in terms of whether they represented authentic life or denied life.

Murphy (2006) has argued against physicalism from scientific data. She argues that the dearth of scientific support for the dualism that has historically shaped Christian understanding is untenable. She speaks of God's actions in the world as being at a quantum ${ }^{1}$ level. Within that conception, there can be no conflict with natural causation within nature. From that perspective, it is possible to assert with Murphy (2006:131) that 'the natural world is intrinsically incomplete and open to divine action at its most basic level'. Moreover, if there is openness to divine action at that most basic level, would it not then be probable to argue that the divine is ontologically present in all of creation as the bond and realm of all reality without any fragmentation or any pantheistic insinuation.

Jones (2010) argues similarly that life cannot be apprehended in reductionist terms and adds that the debate about vitalism transcends everyday scientific concepts. She extends her argument by grounding it in life and characterises it as 'something ... both biologistic and spiritualist, naturalist and theological'. And to that extent, it 'may not have an essence but only be the name for the set of multiple doctrines and movements premised on life variously understood' (Jones 2010:7).

Mupasi as a concept of cosmic s(S)pirit is premised on a positive appraisal of vitalism. When applied for the celebration of life, we step out of the contested space and offer an appreciative appraisal of the value of Mupasi as a source of ecological wisdom. We derive from these insights a life-affirming stance, yet without idolising nature (as in deep ecology). Deane-Drummond (2008) aptly captures the inherent danger of:

\footnotetext{
... a simple appropriation of, for example, spiritual traditions from indigenous cultures in a piecemeal way may have good intentions, but it can also lead to further marginalisation by exclusion from an equal place in the socio-economic sphere. This is the mirror image of the problems with much of liberation theology, where inclusion of one group or 'class' in socioeconomic processes undermines other aspects of indigenous culture. (p. 53)
}

The concept of Mupasi advances an antireductionist view of nature, which can be postulated as a critique of the reductionist and mechanistic approaches to nature. 
The idea of a life principle construed as cosmic spirit is not unique to African thought. Other cultures that regard the universe as an enchanted realm rather than a mechanised system also have such ideas that are akin to Mupasi. The Chinese notion of chi, the Egyptian concept of maat, the Japanese notion of $k i$ and the Hindu idea of prana are some examples among others.

Mupasi derives from a tradition in which God, ancestral spirits, human beings and plants, including non-animate things like minerals, are understood as proceeding from a life force or vital energy (Tempels 1959:31). Ontologically speaking, therefore, Mupasi is an overarching idea of that which holds the web of life together and undergirds cosmological understanding, ethical behaviour and the rituals of the life cycle.

Such a characterisation recalls Tempels' development of the concept of vital force as dynamic hierarchy of interrelationships within the community of life that governs the universe. The Creator, giver of all force, is at the top with the forbearers or ancestors of clans who provide a link between human beings and the creator and the lower inanimate beings and minerals. The hierarchy is premised on 'vital power, rank and primogeniture' (Tempels 1959:43).

Tempels' critics say his notion of vital force advances a cult of difference that is the product of colonial thought (Ngong 2010:77). Another view questions whether, in fact, his idea of vital force is even an African concept or a European imposition (Mbiti 1969:10). The other question is the validity of the concept and if it does not, in fact, gloss over the vast and heterogeneous nature of African cultures.

Despite the contestation of Tempels' idea of vital force, African theologians and African philosophers seem to endorse the methodological validity of the concept. Kaoma (2013), Sakupapa (2012), Magesa (1997), Nkemnkia (1999), Nkurunziza (1989), Nyamiti (1976), Mulago (1962) and Kagame (1956), each, to varying degrees, endorses Tempels' thesis and they appropriate the concept as a valid characterisation of the philosophical underpinning for an enchanted unitary universe.

For instance, Mulago (1962 advances the ideas of union vitale and participation vitale as the God-centeredness (however, God is understood in various African cultures) of communal life within the realm of the cosmic s(S)pirit. God, understood as the Supreme Being, imbues all creatures and (inter) connects them within a web of dynamic and intricate relationships (Kaoma 2013). The dynamism within the web of life is a union-of-life-in-participation that theologically speaking is a pneuma-theological category that echoes the Trinitarian relationship and participation within Christian tradition.

The argument derived from this is that humans being part of the community of life are not merely in relationship with creation. Humans are ontologically interwoven with the rest of creation within the realm of the cosmic s(S)pirit. That biocentric impulse has potential to heighten sensibilities about the intrinsic value of all of creation. Mupasi, the cosmic $\mathrm{s}(\mathrm{S})$ pirit, is ontologically present in (and enfolds) all of creation and unfolds herself in all modes of be-ing. ${ }^{2}$

'Now the earth was formless and empty, darkness was over the surface of the deep, and the Spirit of God was hovering over the waters' (Gn 1:2). The word translated as Spirit derives from the Hebrew word ruach, which denotes wind or breath. Schloss (2012:27) amplifies it to signify 'the dynamically creative and life-giving energy of spirit (that) is associated with the purposeful ordering of word and wisdom'. According to recent studies in Syrian, Punic, Akkadian, Samaritan, Ugaritic and Hebrew, in fact, the verbal root of ruach is rwh, which denotes the atmospheric expanse between heaven and earth that can be calm or turbulent. By derivation, therefore, ruach denotes the 'unfolding and spreading' that (Boff 1997:159) calls the pneumatosphere, an inclusive domain.

Mupasi is the cosmic animating potent force that interpenetrates everything, without being identical to everything, within a panentheistic (rather than a pantheistic) view. That kind of retrieval requires a nuanced account for the continuities and discontinuities between Mupasi and the biblical idea of the cosmic spirit, for which there is little scope for exploration in this article.

\section{Mupasi in Trinitarian and cosmic view}

Trinitarian theology is founded on the personhood of the persona of the three persons in the Godhead. It has been rightly argued that such notions of personhood that have characterised Christian theology were especially brought into sharp focus by Aristotelean and Hegelian conceptions which conceptually identify the Spirit as nous. ${ }^{3}$ That identification casts the Spirit in cognitive self-referential terms (Welker 2006) rather than in cooperative relational ones.

Welker (2006) and Polkinghorne (2006) both argue that besides the theological imperative, interreligious and pluralistic relations demand that the personhood of the Spirit be understood in a more complex way that goes beyond cognitive self-referentiality. Polkinghorne (2001:71ff., 97, 2006) postulates a 'context-sensitive and individualitysensitive' Spirit who is empathetic and acts according to the varying contexts and situations of manifestation as depicted in many biblical texts.

The Spirit's context sensitivity may suggest that she is understood as a nebulous amorphous entity within the Godhead, expected to change according to each encounter

2.The hyphen signifies the rheomodic quality of Mupasi. Rheomodic derives from the Greek root 'rheo' which means 'to flow' and so is captured using the verb form being contra the noun form being (c.f Bohm 1980).

3.Identified in Aristotle as spirit, reason or thought (see Ross 1924). 
and particular context. But Polkinghorne does not present the argument in that way. If that were the case, it would be problematic to account for a Trinitarian Spirit. The Spirit's contextual and individual sensitivity has to do with the Spirit's relationship to God the Creator and to Jesus Christ the Redeemer within the economy of the Trinity as one and the same Spirit and the same indivisible God, present in all of creation.

A sacramental view of creation holds that God and creation are not separated and that creation is most itself when 'completely within God, and can most adequately be expressed with the metaphor spirit ... the empowering spirit that brings all things to fulfilment' (McFague 2008:115-116). The metaphors of water, wind, breath, air, field, force and others are used to speak about the Spirit as the reality in which everything exists in utter dependence. These metaphors also allude to the life-affirming nature of that reality as the power of life and its fulfilment. It suggests an ontology that speaks of the world as being within God. Hodgson (1994) postulates this means:

that the whole world is animated by the Spirit and the Spirit proceeds from the whole world as God's body. It means that the Spirit manifests itself in nature, that the Spirit slumbers in nature and nature cries out to the Spirit. (p. 140)

Accepting this ontological portrayal of the Spirit casts God in profound relational terms towards the world, which potentially is the grounding of our hope in a time when we seek to heal the broken body of creation in the face of the ecological crisis. The ontological narrative of God-inrelationship-with-creation reframes how humans relate to the rest of creation and underscores God's commitment to the world. That commitment is not only in redemptive terms but in an enduring accompanying presence of God through the ubiquitous presence of the Spirit that pervades all reality. McFague's (2008) enduring metaphor of the world as the body of God aptly captures the character of such divine presence:

The world is charged with the grandeur of God and it is so by being most fully itself. God as the body of the world is that body by way of zillions of bodies that compose the universe. There is only one reality: God visible (body) and invisible (spirit), but the latter is known through the former. Everything is suffused, infused, with God's breath and light and power. The World is alive with God - but indirectly, incarnationally. (p. 117)

It would therefore be reductionistic and one-directional to account for the Spirit only as a person within the Godhead while denying her ontological relationship in 'individual' and contextual ways to all of creation. A non-reductionistic rendering of the Spirit takes seriously each manifestation and relationship and is grounded in relationship with Jesus Christ the Redeemer and God the Creator, within a Trinitarian framework. It is within that tension-laden construction that a congruent notion of the universal cosmic Spirit emerges. That Trinitarian undergirding is helpful because it does not require that we resolve or even base the argument on the historical master narrative of the three persons, one substance.
The multidirectional relational orientation also validates the place of humans within the community of life without 'differentiation within the earth community of which we form a part' (Conradie 2004:122). Although forms of hierarchy are legitimate and are part of the distinctive place accorded to humans, according a distinctive place to humans does not require a denial of the intrinsic worth and distinctiveness of other kind within creation. Sally McFague points out that the comparison inherent within the hierarchies does not privilege one species above the other. Her tongue-in-cheek question is eloquent, 'Would a dolphin think that we can swim, a dog be impressed by our sense of smell, or a migrating bird be awed by our sense of direction?' (McFague 1993:120). Hierarchical thinking when universalised is thus not problematic. It is simply a fact of how ecosystems are constituted. To that extent, hierarchies in nature avoid reductionism. By the same token, we acknowledge hierarchies of incremental complexity within material and biological processes as a product of the evolutionary history of earthly life and not an inherent absolute quality that privileges the human species above other species.

African philosophical thought is grounded in $u b u-n t u$, understood 'as a whole-ness and a constant flow of be-ing' (Ramose 1999:51). The $n t u$, the life principle, flows through the entire universe. That life principle $(n t u)$ is what Mambwe culture terms, Mupasi that enfolds organic and inorganic forms of life and all modes of be-ing.

Africanist theologians, thinkers and philosophers have explored this theme from various angles, exploring a world view that portrays human life as inseparably bound up with nature and nature as the medium through which the divine is encountered. Within that world view, humans are defined by their connection to the totality of the community of life (Gitau 2000). Such a conception is imbued with potential for a biocentric theology and philosophy that celebrates 'panvitalism' (Asante 1985), the wholeness of reality. Mupasi, the constant flow of be-ing, inseparably warrants the kinship of all creatures. Sindima (1990) underlines the importance of such an underlying belief, because:

How we think about the world affects the way we live in it. In particular, our understanding of nature - our cosmology - affects the way we understand ourselves, the way we relate to other people, and, of course, the way we relate to the earth and other forms of life. For some time the people of Africa have been influenced by a cosmology inherited from the West: the mechanistic perspective that views all things as lifeless commodities to be understood scientifically and to be used for human ends. Yet these people have an alternative way of looking at the world, an alternative cosmology, which can better serve their cultural development and social justice in an ecological context. This alternative may be called a life-centred way, since it stresses the bondedness, the interconnectedness of all living beings. (pp. 137-138)

Mulago (1962) advances the ideas of union vitale and participation vitale, which emphasise the understanding that the divine is essentially as $s(S)$ pirit. The interconnected nature of the community of life is an outworking of the life 
principle that permeates and connects the interrelated web of 'dynamic and intricate relationships' (Kaoma 2013). In Mulago's parlance, it is the union-of-life-in-participation. It is reminiscent of the pneumatological category of relationshipin-participation of the biblical tradition.

Buitendag (2013) illustrates life-in-participation when, in reference to Proverbs 6:6, he declares the agency of otherkind and uses it as a lens for the complexity of apprehending reality. He further states that it must be a collective endeavour that requires application of a constructive empiricism that transcends idealistic notions of reality. Buitendag employs Marais's The Soul of the White Ant $t^{4}$ as an illustration that expands the contours of the epistemic community to include the ant, and by extension, all otherkind within the community of life. Premised on the wave-particle dualism mode and the indeterminacy of reality, Buitendag offers that Christianity's search for truth must lead to openness to the entirety of the truth. Nature itself is a teacher and revealer of truth. The ant's 'perspective' as entry point into a scriptural passage alters the interpretation of the passage. A strong connection to nature and the nonhuman world can shape our presuppositions. The union-of-life-in-participation makes the natural world a transmitter of wisdom and a dynamic participant (agent) in the community of life. It, as it were, 'declare(s) the glory of God' (Ps 19:1).

Asante (1985) coined the term pan-vitalism that echoes Mulago's union vitale:

Reality is inseparable. The African is kin to all creatures - gods, spirits and nature ... The whole of nature must be understood as sacred because it derives its being from the Supreme Being who is the Creator-Animator of the Universe. (pp. 290, 292)

Sindima (1889) characterises this community of life in terms of an:

African idea of community (that) refers to bondedness; the act of sharing and living in the one common symbol - life - which enables people to live in communion and communication with each other and nature ... (which) allows the stories or life experiences of others to become one's own. (p. 537)

Mupasi, s(S)pirit, expresses the interrelatedness of the divine, the ancestors (Nkemnkia 1999), the living and nature. The African ritual life of the entire life cycle from birth to death depicts that reality. All living beings - including God, spirits and ancestors - share in the principle of life, the s(S)pirit. Even inorganic things share in the principle of life because the universe is imbued with her potency. Every object is a religious symbol that connects humans to the unseen transcendent realm. In traditional Christian parlance, every object is sacramental. Sacrament is 'an external action or rite or object that communicates God or in which one encounters God' (Jenson 1997:62). When we construe the presence of Mupasi in inorganic objects as 'sacramental presence', we preclude any

4. In his Die Siel van die Mier [The Soul of the White Ant] (2007), first published in African 1937) originally written in Afrikaans and later translated into English by Winifred de Kok, Eugene N. Marais explored the organic unity of the termite colony Winifred de Kok, Eugene N. Marais explored the organic unity of the termite colony and compared it with the human pantheistic connotations from the specific elements that apply for the retrieval of the concept in this discussion.

Mupasi stems from living in an enchanted universe in which multiple human and nonhuman actors imbued with potency of the $\mathrm{s}(\mathrm{S})$ pirit impact life in diverse (and invisible) ways. The basic notion of Mupasi as cosmic s(Spirit) is apprehended as the intertwined interplay of participants in an enchanted universe. That interplay is not limited to organic life but includes inanimate (or inorganic) things such as artefacts and charms are understood to be imbued with potency and can affect life in diverse ways. ${ }^{5}$

In traditional African societies, newly born children were draped in beads and charms believed to be imbued with potency to ward off malevolent spirits. The potency of the bead or charm could be said to be 'sacramental'. The 'seen' object suggests to human consciousness the unseen transcendent reality or realm suggested by the seen object.

Daneel (2001) has bridged the realms of African initiated churches and African traditional religions to illustrate how the sacramental view of nature undergirds theology and environmental ethics. The interreligious grassroots' organisation, the Zimbabwean Institute for Religious Research and Ecological Conservation and its affiliates highlight the holistic, communal approaches to earth-keeping that have ensued from this work in Mashonaland. ${ }^{6}$

Parsons (2010:118-122) investigated the encounter between local and development policy in the Zambian Copper mining area. She observes the intertwined interplay of the spiritual realm and concrete experience among miners. They used physical objects that they believe had potency to prevent the misfortune of mine accidents. These practices include the use of Christian prayer and Christian symbols. Even the rocks in the mines had agency in that belief. The mine itself was treated and spoken of as a participating agent in the intertwined web of relationships. Parsons includes a quote in the Bemba language, which when loosely translated as: 'The underground was fine by itself, the rocks were peaceful and dignified until we provoked and aggravated them into action $^{77}$ (Parsons 2010: viii). ${ }^{8}$

Nkemnkia (1999:165) offers that 'African thought has a unified vision of reality in which there is no room for irreducible dichotomies of matter and spirit, religious tension

5.Charms and some certain artefacts are understood to be imbued with power to ward off evil (i.e. preserve life) or indeed to inflict evil (i.e. deny life). Their potency ward off evil (i.e. preserve life) or indeed to inflict evil (i.e. deny life). Their potency
is derived from their presence within the 'realm' of the vital force or as it could be is derived from their presence
summoned by circumstance.

6.See Daneel (2001, Chapter 11), 'Towards an African theology of the environment: The Holy Spirit in creation' for an engagement of the traditional African from a Christian theological point of view, highlighting the Spirit's role as the oasis of life and healer of the land whose presence and action is directed against the lifedenying forces in the universe.

7.'Apene panshi pali ikalila [sic], amabwe ayatondolo [sic], ayabukata ifwe twayo yatendeka, twayabalalmuna [sic]'

8.1 bypass Parsons' (2010:viii) translation, 'The underground world lived peacefully with its divine rocks until we provoked and frustrated them', in order to capture the
with particular nuance of the agency of the underground rocks implied in the Bemba particular nuance of the agency of the underground rocks implied in the Bemba
rendering. Secondly, it is to render it in the way I understand it in my capacity as a home-grown speaker of the Bemba language. 
and daily life between soul and body'. That ontologically and metaphysically renders the universe sacred and biocentric. It is so suffused with life that even inanimate objects are 'charged' with the potency of the principle of life-in-participation.

The principle of life is a fundamental value and all things, animate and inanimate, are grounded in it. It 'is the creative force behind all human and non-human action' (Nel 2008:40). Setiloane (1998:80) calls it an 'interpenetrating and permeating' influence that saturates the community of life. Setiloane (1998) asserts that in this assessment, all creation emanates from a single source; therefore:

[T] he term community is inclusive of all life (bios): animals, the habitat (the land), flora, and even the elements. The success of life is found in the ability to maintain a healthy relationship with all. (p. 79)

\section{Mupasi as relational inclusivity}

Nel (2008) extends upon Setiloane's assertion when he frames this relational inclusivity within ecological ethical responsibility. He affirms that:

The most common feature of this cosmology is the integration of three distinguishable aspects, namely environment, society, and the spiritual. All activities are informed by this holistic understanding so that they singularly or collectively maintain or transform the socio-cultural and spiritual landscape. An act is never separated from its environmental, societal, or spiritual impact. The cosmology becomes visible in that indigenous knowledge informs acts of technology, agriculture, animal keeping, music, song, dance, ritual, family ... etc. It is a system of thought embedded in action. One may even go so far as to state that this thought structure is embodied. (pp. 37-38)

In Acts 17, the Spirit is the milieu in whom everything exists. In incarnational terms, life is being with and in God. The Christian scriptures use metaphors of water, breath and air to indicate creation's dependence on God for its growth and flourishing within an interpenetrating and permeating realm of the Spirit. Sally McFague (2008) sums up the message of Acts 17 as an:

understanding (that) says that we live within the body of God; that the world is, and is not the body of God; and that all things exist within the one reality that is and that reality is on the side of life and fulfilment. God as Spirit is the power of life and love within which all bodies exist. (p. 116)

The inclusivity suggested by the interpenetrative and permeating power of Mupasi in the universe recalls the imbedded and embodied nature of life. It should engender moral responsibility towards the community of life to inspire healing action towards creation. The convergence insights, held in critical relationship, could lead to an ethic that resists the abuse of creation premised on the belief that all creatures in the community of life have intrinsic value because life is bound up in the dialectic of the collective. When humans are spoken of as subject, they can only be spoken of in terms of intersubjective relationship with otherkind. Humans are therefore not subjects in the abstract. They are subjects in relation to other subjects.
The ecological crisis the world faces could be characterised as a loss of equilibrium and a reminder that human relations with otherkind in creation is in disequilibrium. Humans have ceased to see the glory of God in everything in the world. McFague (2008) admonishes against human failure when she opines that:

We must undergo the deepest of all conversions, the conversion from egocentrism to theocentrism; a conversion to whom we truly are: reflections of God, as is everything in creation. The only difference between us and the rest of creation is that the others reflect God, tell of God, simply by being, whereas we must will that it be so. We must desire ... to live justly and sustainably on earth with all other creatures. (p. 115)

The 'other' includes God, the living and the living-dead and all that is in the environment. Everything is interrelated. Therefore, life lived in balance is directed towards the flourishing of all of creation. The sacredness, bondedness and fecundity of the community of life leads to communal equilibrium as Mupasi undergirds the life cycle. The community's rites of intensification ${ }^{9}$ mark the various stages, seasons of life, rites of passage and communal rites. Through these rites, the ubiquitous presence of Mupasi in all her vicissitudes is acknowledged and celebrated as the 'realm' of life (Lugira 2009).

Even death is an acceptable natural part of the life cycle (Lugira 2009) with such a realm. The life cycle is just that, a LIFE-cycle. Even death leads to (becomes) life. The solidarity between the living and the living-dead is also appropriated as ecclesiologically, Christologically and eschatologically relevant (see Mbiti 1969; Pobee 1979; Sawyerr 1970). The interrelatedness of life beyond the human scope to include all of life underlies respect for life even beyond death. The community of life does not cease at death when relationality undergirds ontology. Interaction within (inter)relationship entails the self-extension of the community of life. Interrelations within it constantly regenerate and renew, even in death. That is the essence of life. Be-ing is in becoming ${ }^{10}$ because life has the highest value (Nkurunziza 1989:129; Okafor 1982:91). Life is invoked even in funeral rites. The origins of life in African mythology do not preclude death. Creation myths recount the origins of humans and all created beings alongside death (cf. Lugira 2009; Nalwamba 2014).

Valorising ritual rites is contentious because ritual and rites are not always life-affirming. They normalise life-denying elements, such as the subjugation of women. The positive retrieval of the life-affirming dimensions of the concept of Mupasi in this discussion is not an endorsement of such base

9.This concept is applied to congregational studies but it also describes what we are discussing here (see Ammerman et al. 1998). Rites of intensification are rituals that focus the community and strengthen (intensify) the community's commitment to its beliefs and shared meanings. These include especially those rituals, which celebrate or focus on the core values of the community. In African traditional life, these include all the rituals that mark the cycle of life from conception to afterlife; the include all the rituals that mark the cycle of life from conception to afterlife; the cycle of seasons and the celebration around the sacred objects within nature like trees, rivers, mountains, animals and the spirits which are revered and understood
to sustain and nourish life.

10.Eberhard Jungel has written a book by this title which marks the self-communicative movement through which God makes God present to us; God's sending the Son in movement through which God makes God present to us; God's sending the Son in
the unity of the Spirit into the world which overcomes the antitheses of 'being' and 'relationship' (see Jungel 2014). 
elements. In other words, we do not seek to absolutise the concept. The retrieval is necessarily selective.

\section{Echoes of Mupasi in the Bible}

This retrieval takes the view that all of creation, not just Christian people, are endowed with God's Spirit (Gn 2:7; Acts 2:17). Consequently, the $\mathrm{s}(\mathrm{S})$ pirit is not confined to Christians. That understanding opens up avenues that truth is present in the realm of life and experience outside the Christian faith. The possibility for exploration exists within the purview of the universality of the $\mathrm{s}(\mathrm{S})$ pirit. The truth and wisdom of other cultures and traditions could enlighten, enrich and inform Christian theology and praxis. Wisdom literature captures the continuum of incursion of the s(S)pirit in everything that exists. The expansiveness of the $s(S)$ pirit exudes life. The Spirit is present at every convergence within the community of life. The concept of Mupasi puts that insight into sharp focus. When appropriated theologically, it fundamentally anchors the notion of the $s(S)$ pirit as the foundation of a relational, interrelated conception of reality.

The expansiveness of the Spirit is depicted as Wisdom present from the beginning and as realm of life. Proverbs 8:22-31 is an example:

The LORD brought me forth as the first of his works, before his deeds of old; I was formed long ages ago, at the very beginning, when the world came to be. When there were no watery depths, I was given birth, when there were no springs overflowing with water; before the mountains were settled in place, before the hills, I was given birth, before he made the world or its fields or any of the dust of the earth. I was there when he set the heavens in place, when he marked out the horizon on the face of the deep, when he established the clouds above and fixed securely the fountains of the deep, when he gave the sea its boundary so the waters would not overstep his command, and when he marked out the foundations of the earth. Then I was constantly at his side. I was filled with delight day after day, rejoicing always in his presence, rejoicing in his whole world and delighting in mankind.

Mupasi is thus plausibly a dialogue partner of Christianity for the articulation of a pneuma-theological category for a holistic view of life that contributes to global Christian ecological discourse.

This retrieval does not seek to conflate views. The syncretism critique is well founded. To address it, we take a leaf from Boff (1997) who makes a case for a positive view of syncretism ${ }^{11}$ by suggesting that it is by digesting some aspects of alien systems of thought that religion nourishes itself. The

11.While appreciating the potential distraction that the use of the term syncretism may cause, we use it advisedly. The question that has arisen many times when discussing this project with many Christian friends is if it proposes a return to animism by suggesting that such a concept would provide adequate grounds for the articulation of an adequate pneuma-theological category. Boff's ideas in relation to liberation theology, in general, and the Catholic Church in particular, are varied. The particular reference here is to his views about a pneumatic ecclesiology varied. The particular reference here is to his views about a pneumatic ecclesiology of the primitive Church's dynamics of community, cooperation and charism as the bases of a non-hierarchical church and existence. His theologising is born from his own South American context of comunidades eclesiales de base [or bas communities], where participation challenges hierarchy and creates instead community based on commonality and equality, all this without understanding this as a kind of utopian aspiration but as an outflow of the Christian faith and recall of its history as well. biological metaphors he employs clearly indicate that what he argues for does not include negative views of syncretism. The part of the organism that feeds off another does not require changing its identity. He therefore disavows loss of history and identity. The syncretism he speaks of is cognisant of continuity and discontinuity. A 'substantial nucleus' exists that represents the history and identity.

In this discussion, part of the 'substantial nucleus' of Christian tradition that has been brought into sharp focus through the hermeneutical lens of Mupasi is that the creator Spirit lives in and bequeaths life to all of creation has life. Without God's Spirit, there can be no life. The biblical account speaks about $\mathrm{s}(\mathrm{S})$ pirit in a continuum. From a sacramental standpoint then, we assert that creation, suffused with life, love, inclusiveness and equality, is a manifestation of the $s(S)$ pirit understood within a holistic pneuma-theology.

\section{Conclusion}

The retrieval of the idea of Mupasi as the cosmic s(S)pirit, attempted here, brings into sharp focus the power of God that gives life (ruach) as a layered, coexistent way of be-ing that transcends material-spiritual binaries. It also casts human as ontologically related to the rest of creation. The s(S) pirit makes possible a unitary reality in which immanence and transcendence are inextricably bound up as a realm in which the presence of God may be discerned. The cosmic s(S) pirit is apprehended within a Trinitarian frame of reference that enables communion (life-in-participation) in the web of life. Such a view enhances appreciation of and inspires ethical actions towards nature within broader redemptive and eschatological dimensions of a Christian pneuma-theology.

\section{Acknowledgements Competing interests}

The author declares that he has no financial or personal relationships which may have inappropriately influenced him in writing this article.

\section{References}

Ammerman, N.T., 1998, 'Culture and identity in the congregation', in N.T. Ammerman, W.C. Jackson, C.S. Dudley, \& W. McKinney (eds.), Studying congregations: A new handbook, pp. 78-104, Abingdon Press, Nashville, TN.

Asante, E., 1985, 'Ecology: Untapped resource of pan-vitalism in Africa', AFER: African Ecclesial Review 27, 289-293.

Boff, L., 1997, Cry of the earth, cry of the poor, Orbis, Minneapolis, MN.

Buitendag, J., 2013, 'Gaan na die mier, kyk na sy weë en word wys: Metafoor?', HTS Teologiese/Theological Studies 69(1), Art. \#1976, 1-9.

Conradie, E., 2004, 'On the integrity of the human person and the integrity of creation: Come Christian theological perspectives', in C. du Toit (ed.), The integrity of the human person in an African context: Perspectives from science and religion, $\mathrm{pp}$. 107-151, Research Institute for Theology and Religion, University of South Africa, Pretoria.

Conradie, E., 2014, 'What on earth did God create? Overtures to an overtures to an', The Ecumenical Review 64(4), 433-453. https://doi.org/10.1111/erev.12120

Daneel, M., 2001, African earthkeepers: Wholistic inerfaith mission, Orbis, Maryknoll, NY.

Deane-Drummond, C., 2008, Eco-theology, Anselm Academic, Winona, MN.

Faraday, M., 1849, Experimental researches in electricity, 2nd edn., Richard \& Edward Taylor, London.

Gitau, S., 2000, The environmental crisis: A challenge for African Christians, Acton, Nairobi. 
Hodgson, P., 1994, Winds of the spirit: A constructive Christian theology, SCM Press, London.

Jenson, R., 1997, Systematic theology: The Triune God, Oxford University Press, New York.

Jones, D., 2010, The racial discourses of life philosophy: Negritude, vitalism and modernity, New Directions in Critical Theory ed., Columbia University Press, New York.

Jungel, E., 2014, Being is in becoming: The trinitarian of God in the theology of Karl Barth, Bloomsbury, London.

Kagame, A., 1956, La Philosophie Bantu-Rwandaise de l'étre, Academie Royale des Sciences Coloniale, Bruxelles.

Kaoma, J.K., 2013, God's family, God's earth: Christian ecological ethics of Ubuntu, Kachere Series, Zomba.

Lugira, A., 2009, African traditional religion (world religions), 3rd edn., Chelsea House Publishers, New York.

Magesa, L., 1997, African religion: The moral traditions of abundant life, Orbis Books, Mary Knoll, NY.

Marais, E.N., 1937, Diel Siel van die Mier, Methuen \& Co Ltd, London.

Marais, E.N., 2007, Die Siel van die Mier, S.F. Honing, J.C. Kannemeyer, A. Klopper, L. Louw \& M. Oosthuizen (reds.), Protea Boekhuis, Pretoria.

Mbiti, J., 1969, African religions and philosophy, Heinemann, Oxford.

McFague, S., 1993, The body of God: An ecological theology, Fortess Press, Minneapolis, MN.

McFague, S., 2008, A new climate for theology: God, the world, and global warming, Fortess Press, Minneapolis, MN.

Mulago, V., 1962, Un visage africaine du Christianisme, Presence Africaine, Paris.

Murphy, N., 2006, Bodies and souls, or spirited bodies?, Cambridge University Press, Cambridge.

Nalwamba, K., 2014, 'Spirited bodies' as a prerequisite for an earth-keeping ethos: A juxtaposition of the first creation story of genesis with Ubuntu cosmogony, African Theological Monographs, 1st edn., Scholarium, Cluj-Napoca.

Nalwamba, K.M.B. \& Buitendag, J., 2017, 'Vital force as a triangulated concept of nature and s(S)pirit', HTS Teologiese Studies/Theological Studies 73(3), 4506. https://doi.org/10.4102/hts.v73i3.4506

Nel, P., 2008, 'Morality and religion in African thought', Acta Theologica 2, 33-47.

Ngong, D., 2010, The Holy Spirit and salvation in African Christian theology: Imagining a more hopeful future for Africa, Peter Lang, Oxford.

Nkemnkia, M., 1999, African vitalogy: A step forward in African thinking, Paulines Publications Africa, Nairobi.
Nkurunziza, D., 1989, Bantu philosophy of life in the light of the Christian message: A basis for an African vitalist theology, Peter Lang, New York.

Nyamiti, C., 1976, African tradition and the Christian God, Gaba Publishers, Eldoret.

Okafor, S. O., 1982, 'Bantu philosophy: Placide temples revisited', Journal of Religion in Africa 13(2), 83-100.

Parsons, E., 2010, What price for privatisation?: Cultural encounter with development policy on the Zambian copperbelt, Lixington Books, Lanham.

Pobee, J., 1979, Towards an African theology, Abingdon, Nashville, TN.

Polkinghorne, J., 2001, Faith in the living God: A dialogue, SPCK, London.

Polkinghorne, J., 2006, 'The hidden spirit and the cosmos', in M. Welker (ed.), The work of the spirit: Penumatology and pentecostalism, pp. 169-182, William B. Eerdmans, Grand Rapids, MI.

Ramose, M., 1999, African Philosophy through Ubuntu, Mond Books, Indiana.

Ross, W., 1924, 'Commentary', in W. Ross (ed.), Aristotle's Metaphysics Volume 1: A Revised text with introduction and commentary by W.D. Ross, pp. 114-366, Clarendon Press, Oxford.

Sakupapa, T., 2012, 'Spirit and ecology in the context of African theology', Scriptura 3(111), 422-430.

Sawyerr, H., 1970, God: Ancestor or creator? Aspects of traditional belief in Ghana, Nigeria and Sierra Leone, Longman, London.

Schloss, J., 2012, 'Hovering over the waters: Spirit and the ordering of creation', in M. Welker (ed.), The spirit in creation and new creation: Science and theology in Western and Orthodox Realms, pp. 26-49, William B. Eerdmans, Grand Rapids, MI.

Setiloane, G., 1998, 'Towards a biocentric theology and ethic - Via Africa', in C. du Toit (ed.), Faith, science \& African culture. African cosmology and Africa's contribution to science, pp. 73-84, UNISA, Pretoria.

Sindima, H., 1989, 'Community of life', The Ecumenical Review 41(4), 537-551. https://doi.org/10.1111/j.1758-6623.1989.tb02610.x

Sindima, H., 1990, 'Community of life: Ecological theology in African perspective', in C. Birch, W. Eaken \& J.B. McDaniel (eds.), Liberating life: Contemporary approaches in ecological theology, pp. 137-147, Orbis Books, Maryknoll, NY.

Tempels, P., 1959, Bantu philosophy, Editions Réclame, Paris.

Walls, A., 1984, Culture and coherence in Christian history: The Finlayson lecture for 1984, pp. 1-9, University of Aberdeen, Aberdeen.

Welker, M., 2006, 'The spirit in philosophical, theological and inter-disciplinary perspectives', in M. Welker (ed.), The work of the spirit: Pneumatology and pentecostalism, pp. 221-232, William B. Eerdmans, Grand Rapids, MI. 